\title{
Congenital Depressed Skull Fracture Lifting with Suction Cup: A Therapeutic Alternative to Surgery
}

\author{
André Tokpa', Louis Derou', Konan Serge Yao ${ }^{1}$, Oka Dominique N'dri² \\ ${ }^{1}$ Department of Neurosurgery, Teaching Hospital of Bouaké, Bouaké, Cote d'Ivoire \\ ${ }^{2}$ Department of Neurosurgery, Teaching Hospital of Yopougon, Abidjan, Cote d'Ivoire \\ Email: valentin_tokpa@yahoo.fr
}

How to cite this paper: Tokpa, A., Derou, L., Yao, K.S. and N'dri, O.D. (2019) Congenital Depressed Skull Fracture Lifting with Suction Cup: A Therapeutic Alternative to Surgery. Open Journal of Modern Neurosurgery, 9, 115-122.

https://doi.org/10.4236/ojmn.2019.92011

Received: January 21, 2019

Accepted: March 23, 2019

Published: March 26, 2019

Copyright $\odot 2019$ by author(s) and Scientific Research Publishing Inc. This work is licensed under the Creative Commons Attribution-NonCommercial International License (CC BY-NC 4.0). http://creativecommons.org/licenses/by-nc/4.0/

\begin{abstract}
Congenital skull fractures of newborn are rare and create medico-legal problems. Their management is controversial. Between surgery considered too aggressive and uncertain conservative attitude, reduction by suction cup or breast pump is an alternative. The authors report their experience through a case of successful resolution of a congenital depressed skull fracture using a suction cup in a newborn at 13 day of life followed by a literature review. This technique avoids the usual complications of surgery and reduces the anxiety of parents related to surgery. It also avoids the anxiety of having a newborn with a recessed skull and a conservative attitude with uncertain outcome.
\end{abstract}

\section{Keywords}

Congenital Skull Fracture, Depressed Skull Fracture, Suction Cup

\section{Introduction}

Depressed skull fracture in "Ping-Pong" is specific to newborn and infant because of the elasticity of the developing bone that allows an indentation without rupture.

It usually occurs after traumatic birth. However, they can occur during the antenatal period. The diagnosis is often made at birth and gives rise to serious problem of medical liability. In fact, it is impossible in case of obstetric maneuvers or associated instrumental extraction, to distinguish spontaneous depressed skull fractures from those induced by trauma [1], even if these last ones are significantly more likely associated to intracranial lesions [2].

The treatment of these depressed skull fractures is controversial. It differs ac- 
cording to the authors. Indeed, some authors propose a surgical abstention considering the possibility of spontaneous resolution; others on the other hand suggest a surgical management. Between these two modalities, there is lifting by suction maneuver, especially with a suction cup or a breast pump. We report our experience of congenital depressed skull fracture lifting with suction cup. The goal of this paper is to demonstrate the validity of a procedure that could be performed with a minim risk on patient by avoiding more aggressive surgery.

\section{Case Report}

A male infant was born at 37 weeks of gestation by caesarean section due to presence of a placenta praevia. His mother was 30 years old and primiparous. Birth weight was $3600 \mathrm{~g}$ and head circumference at birth was 33 centimeters. The presentation was cephalic. The Apgar score was respectively 9, 9 and 10 in one, five and ten minutes. The pregnancy history was without any particularity. There was no mention of abdomino-pelvic trauma nor uterine myoma. A left parietal skull depression of 5 centimeters in diameter and $3 \mathrm{~cm}$ in depth was noted at birth (Figure 1). There was no edema or subcutaneous hematoma with regard to depression. The anterior fontanel was normal. No sign of intracranial hypertension were detected.

The obstetrician requested a neurosurgery opinion. The CT-scan confirmed the depressed skull fracture without associated parenchymal lesion (Figure 2). We initially opted for conservative management and explained to the family the possibility of spontaneous resolution. However, one week after birth, parents consult again and express their anxiety. This led us to propose lifting the depressed skull fracture by using a suction cup at 13 days of life.

The suction cup was placed over the depressed region for obtaining the airtight seal between the scalp and the cup (Figure 3). A gradual aspiration was carried out until the depressed skull fracture is reduced. The maneuver was performed under general anesthesia.

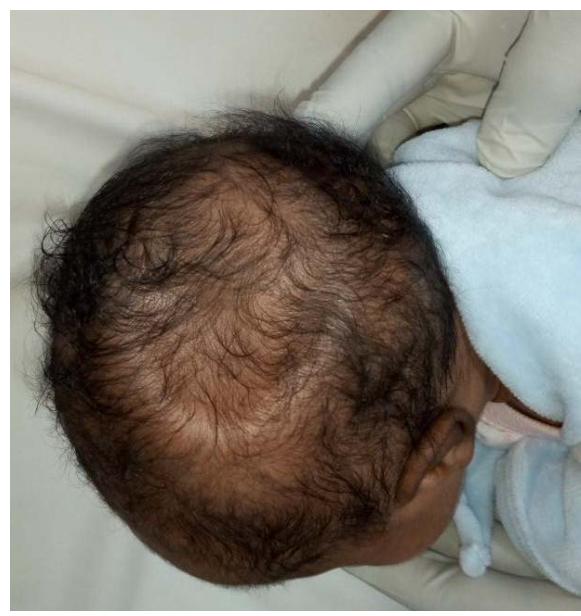

Figure 1. Picture of the newborn showing a depression of the skull. 


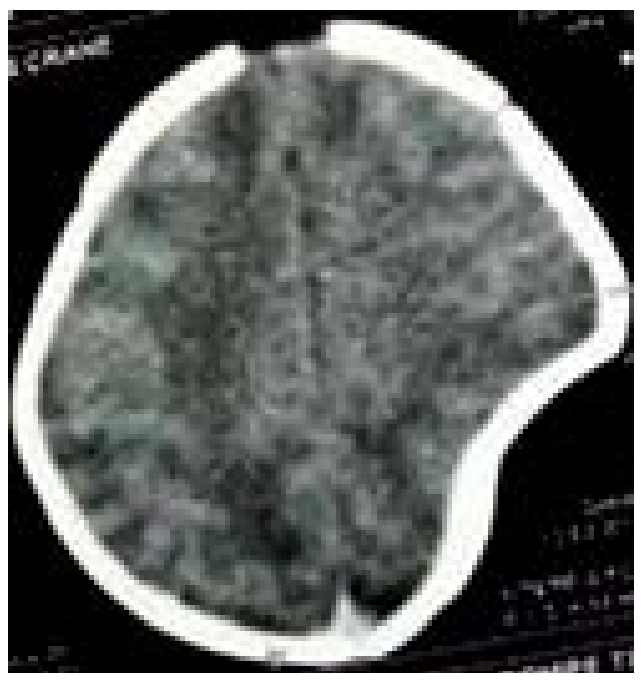

Figure 2. CT scan showing no parenchymal lesion.

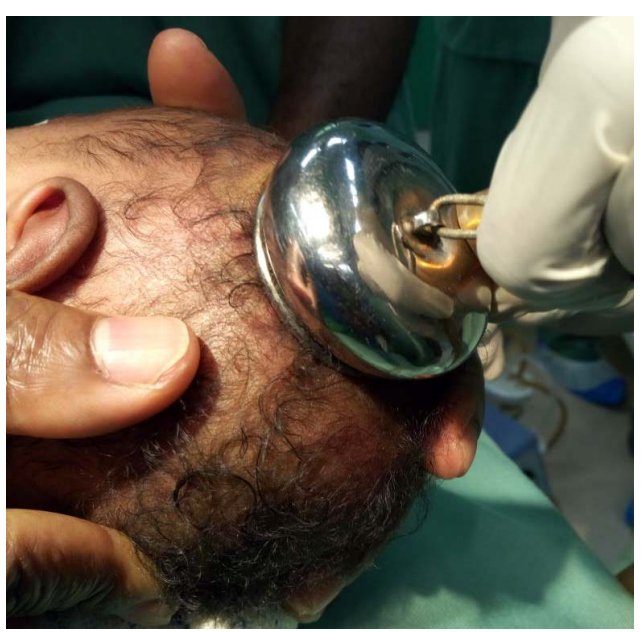

Figure 3. Technique of lifting the depressed skull fracture with a sucker.

In addition, there was a swelling at the site of application of the suction cup after the procedure (Figure 4). The newborn was discharge the day after.

The controls 3 months and one year later showed integral resolution and normal psychomotor development. There was no notion of epileptic seizure.

\section{Discussion}

Congenital depression of the skull is relatively rare. Their incidence is estimated between 1 and 3 per 10,000 live births [3]. During the last ten years, 16 cases of congenital depression of the skull have been published (Table 1). This injury is a source of anxiety for parents. Congenital discomfort is the result of excessive and/or prolonged pressure on the skull during intra-uterine life or delivery [4]. There are multiple causes, including maternal abdominopelvic trauma, forceps use, uterine fibroids, vicious fetal presentations, fetal skull compression by the 


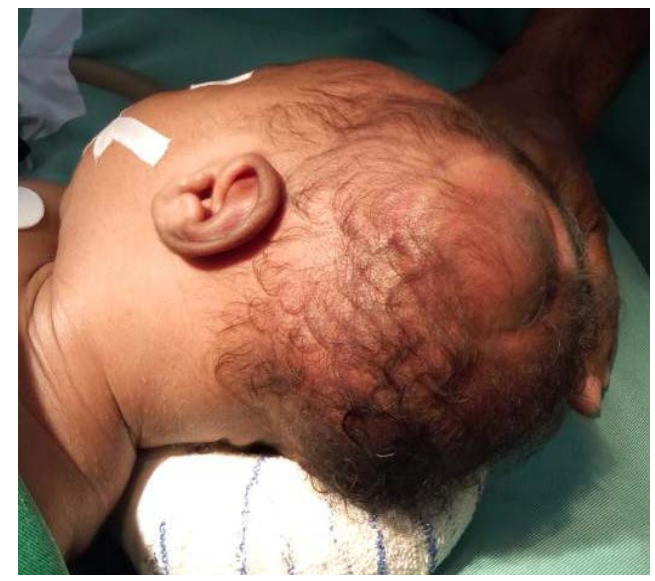

Figure 4. Depressed skull fracture lifting.

limbs, the head of a twin, or maternal bone structures such as L5 vertebra, promontory, pubic symphysis and ischium [5] [6]. These discomforts are not favored by maternal age, parity, gestational age, type of delivery, and fetal weight [5].

The consequences of these skull depressions seem to be mainly aesthetic. On the 16 cases collected in the literature these last 10 years, no case of sensitivo-motor deficit or psychomotor disorder was reported. It was believed for a long time that patients with congenital skull depression had an increased risk of seizures. In addition, some authors have expressed the concern that the pressure exerted by depression on the brain parenchyma may cause functional brain damage, a decrease in cerebral blood flow, and epileptogenic foci thus explaining the value of surgical treatment.

However, several studies since the 1960s have shown that for children without neurological sequelae or radiographic evidence of intracranial injury, there was no difference between surgically and non-surgically treated patients in terms of future neurological damage or epileptics seizures [3] [7] [8].

From then on, the surgical lifting which was for long time the rule is increasingly questioned, reinforced by the numerous cases of spontaneous reduction reported.

Spontaneous resolution can occur because the newborn and the infant skull are thin and flexible thus it can be remodeled [9].

Among the 16 cases published these past 10 years, 9 were treated surgically and 7 were conservatively. This shows that surgery still have an important place in the management of this lesion. This surgery is also a source of anxiety for parents just like having a newborn with down skull. The outcome of the conservative attitude is uncertain with a period of spontaneous resolution up to 6 months [10]. On the other hand, there is little information to help clinicians to accurately predict which depressed skull fracture will reduce spontaneously. Usually, larger and deeper depressions are dealt more aggressively. However, the treatment remains uncodified. 
Table 1. Reports in literature.

\begin{tabular}{|c|c|c|c|c|c|c|c|c|}
\hline References & $\begin{array}{l}\text { Maternal } \\
\text { age }\end{array}$ & $\begin{array}{c}\text { Gestation } \\
\text { al age at } \\
\text { birth }\end{array}$ & $\begin{array}{c}\text { Maternal } \\
\text { associated } \\
\text { pathology with } \\
\text { pregnancy }\end{array}$ & $\begin{array}{l}\text { Type of } \\
\text { delivery }\end{array}$ & $\begin{array}{c}\text { Skull } \\
\text { depression } \\
\text { dimension }\end{array}$ & $\begin{array}{l}\text { Neurological } \\
\text { manifestation }\end{array}$ & Treatment & $\begin{array}{l}\text { Follow-up } \\
\text { outcome }\end{array}$ \\
\hline $\begin{array}{l}\text { Fantacci C } \\
\text { and col. [5] }\end{array}$ & unspecify & $\begin{array}{l}\text { born at } \\
\text { term }\end{array}$ & none & $\begin{array}{l}\text { elective cesarean } \\
\text { section at the } \\
\text { request of the } \\
\text { parturient }\end{array}$ & unspecify & none & $\begin{array}{l}\text { surgery at } \\
\text { 3rd day }\end{array}$ & $\begin{array}{l}\text { immediate full } \\
\text { resolution }\end{array}$ \\
\hline $\begin{array}{l}\text { Gezmu AM } \\
\text { and col. [6] }\end{array}$ & 27 years & 41 weeks & none & $\begin{array}{l}\text { caesarean section } \\
\text { for seat presenta- } \\
\text { tion }\end{array}$ & $\begin{array}{l}\text { diameter: } \\
3 \mathrm{~cm} \\
\text { depth: } \\
2.5 \mathrm{~cm}\end{array}$ & none & $\begin{array}{l}\text { surgery at } \\
\text { 8th day }\end{array}$ & $\begin{array}{l}\text { immediate full } \\
\text { resolution }\end{array}$ \\
\hline $\begin{array}{l}\text { Agrawal S K } \\
\text { and col. [9] }\end{array}$ & 28 years & $\begin{array}{l}\text { born at } \\
\text { term }\end{array}$ & none & $\begin{array}{l}\text { caesarean } \\
\text { section }\end{array}$ & $\begin{array}{l}\text { diameter: } \\
4 \mathrm{~cm} \\
\text { depth: } 1 \mathrm{~cm}\end{array}$ & none & conservative & $\begin{array}{l}\text { full resolution in } 6 \\
\text { months }\end{array}$ \\
\hline $\begin{array}{l}\text { Huang Y and col. } \\
\text { [3] }\end{array}$ & unspecify & 38 weeks & none & $\begin{array}{c}\text { caesarean } \\
\text { section for } \\
\text { (occipitotransvers } \\
\text { position) }\end{array}$ & $\begin{array}{l}\text { diameter: } \\
5 \mathrm{~cm} \\
\text { depth: } 2 \mathrm{~cm}\end{array}$ & none & conservative & $\begin{array}{l}\text { full resolution in } 4 \\
\text { months }\end{array}$ \\
\hline $\begin{array}{l}\text { Tovar-Spinoza ZS } \\
\text { and col. }[13]\end{array}$ & unspecify & $\begin{array}{l}\text { born at } \\
\text { term }\end{array}$ & HIV Infection & vaginal delivery & unspecify & none & $\begin{array}{l}\text { surgery at } \\
13 \text { th day }\end{array}$ & $\begin{array}{l}\text { immediate } \\
\text { partial resolution }\end{array}$ \\
\hline $\begin{array}{l}\text { Dharmaraj S T } \\
\text { and col. [14] }\end{array}$ & unspecify & $\begin{array}{l}\text { born at } \\
\text { term }\end{array}$ & none & $\begin{array}{l}\text { caesarean section } \\
\text { for failure of work } \\
\text { progression }\end{array}$ & $\begin{array}{l}\text { diameter: } \\
6 \mathrm{~cm} \\
\text { depth: } 2 \mathrm{~cm}\end{array}$ & none & $\begin{array}{l}\text { surgery at } 2 \\
\text { week of life }\end{array}$ & full resolution \\
\hline $\begin{array}{c}\text { Suneja U and col. } \\
\text { [15] }\end{array}$ & unspecify & 40 weeks & none & $\begin{array}{l}\text { caesarean section } \\
\text { for fetal distress }\end{array}$ & $\begin{array}{l}\text { diameter: } \\
4.5 \mathrm{~cm} \\
\text { depth: } 0.5 \\
\mathrm{~cm}\end{array}$ & none & conservative & full resolution \\
\hline & 30 years & $\begin{array}{l}\text { born at } \\
\text { term }\end{array}$ & none & vaginal delivery & unspecify & $\begin{array}{c}\text { occurrence of } \\
\text { epileptic seizure }\end{array}$ & conservative & full reduction \\
\hline $\begin{array}{l}\text { Arifin } \mathrm{MZ} \text { and col. } \\
\text { [16] }\end{array}$ & 21 years & $\begin{array}{l}\text { born at } \\
\text { term }\end{array}$ & none & vaginal delivery & $\begin{array}{l}\text { diameter: } \\
2 \mathrm{~cm} \text { depth: } \\
2 \mathrm{~cm}\end{array}$ & none & surgery & full resolution \\
\hline $\begin{array}{c}\text { Aliabadi } \mathrm{H} \text { and col. } \\
{[7]}\end{array}$ & 36 years & 39 weeks & none & $\begin{array}{l}\text { caesarean section } \\
\text { for failure of work } \\
\text { progression }\end{array}$ & unspecify & none & surgery & full resolution \\
\hline \multirow{2}{*}{$\begin{array}{l}\text { Basaldella L } \\
\text { and col. [17] }\end{array}$} & 40 years & 38 weeks & none & $\begin{array}{l}\text { caesarean section } \\
\text { for failure of work } \\
\text { progression }\end{array}$ & unspecify & none & conservative & $\begin{array}{l}\text { full resolution in } 8 \\
\text { month }\end{array}$ \\
\hline & 41 years & 36 weeks & none & $\begin{array}{l}\text { caesarean section } \\
\text { for failure of work } \\
\text { progression }\end{array}$ & unspecify & none & conservative & $\begin{array}{l}\text { full resolution in } 8 \\
\text { month }\end{array}$ \\
\hline $\begin{array}{c}\text { Staels } W \text { and col. } \\
\text { [18] }\end{array}$ & unspecify & 38 weeks & none & $\begin{array}{l}\text { vaginal delivery } \\
\text { assisted by } \\
\text { suction cup }\end{array}$ & $\begin{array}{l}\text { diameter: } 4 \\
\text { cm depth: } \\
0.5 \mathrm{~cm}\end{array}$ & none & $\begin{array}{l}\text { surgery due } \\
\text { to an } \\
\text { associated } \\
\text { cerebral } \\
\text { contusion }\end{array}$ & full resolution \\
\hline
\end{tabular}




\section{Continued}

\begin{tabular}{|c|c|c|c|c|c|c|c|c|}
\hline $\begin{array}{l}\text { Preston D and col. } \\
{[19]}\end{array}$ & 28 years & $\begin{array}{c}38 \\
\text { weeks + } \\
4 \text { days }\end{array}$ & $\begin{array}{l}\text { high blood } \\
\text { pressure and } \\
\text { pre-eclampsia }\end{array}$ & $\begin{array}{c}\text { caesarean section } \\
\text { for fetal distress }\end{array}$ & $\begin{array}{c}\text { diameter: } \\
3 \mathrm{~cm} \\
\text { depth: } 3 \mathrm{~cm}\end{array}$ & none & conservative & $\begin{array}{l}\text { full resolution } \\
\text { in } 6 \text { month }\end{array}$ \\
\hline \multirow{2}{*}{$\begin{array}{l}\text { Veeravagu A. } \\
\text { and col. [20] }\end{array}$} & unspecify & $\begin{array}{l}39 \text { weeks } \\
+5 \text { days }\end{array}$ & none & vaginal delivery & unspecify & none & surgery & full resolution \\
\hline & unspecify & 38 weeks & none & vaginal delivery & unspecify & none & surgery & full resolution \\
\hline
\end{tabular}

Between surgical treatment considered too aggressive for a newborn child with a potentially self-limiting lesion and uncertain conservative treatment, vacuum reduction with a suction cup or breast pump is an alternative. This last therapeutic treatment which can be done without general anesthesia, is less aggressive and allows an immediate resolution [11] [12]. It helps avoid thereby the most common complications of surgery, including infection, bruising and blood loss. The breast pump seems more advantageous than the suction cup. Indeed the transparency of the breast pump allows observing in real time the lifting of the depression. Moreover it seems less aggressive than metal suction cup. In addition, it seems less aggressive than the metal suction cup. Therefore it avoids the temporary marks left on the scalp by the vacuum metal like in our case [11].

\section{Conclusion}

Skull Congenital depression, although rare and usually benign, still raises problems of therapeutic management because it is not yet codified. Between conventional surgical treatment, considering too aggressive and conservative attitude long and uncertain, we suggest the technique of reduction by suction cup or breast pump which is a less aggressive and effective alternative.

\section{Conflicts of Interest}

The authors declare no conflicts of interest regarding the publication of this paper.

\section{References}

[1] Chauvet, A., Boukerrou, M., Nayama, M., Dufour, P. and Puech, F. (2005) Traumatismes crâniens obstétricaux spontanés: Mythe ou réalité [Spontaneous Intrauterine Depression Skull: Myth or Reality]? Gynécologie Obstétrique \& Fertilité, 33, 582-585. https://doi.org/10.1016/j.gyobfe.2005.06.018

[2] Dupuis, O., Silveira, R., Dupont, C., et al. (2005) Comparison of "Instrument-Associated" and "Spontaneous" Obstetric Depressed Skull Fractures in a Cohort of 68 Neonates. American Journal of Obstetrics \& Gynecology, 192, 165-170. https://doi.org/10.1016/j.ajog.2004.06.035

[3] Huang, Y.J., Zhuang, J.W., Chen, Y.Z. and Li, W.Z. (2016) Congenital Skull Depression in a Newborn. Delivered by Cesarean Section due to Continued Occipitotransverse Position: Case Report and Short Communication. International Journal of Neurology and Neurotherapy, 3, Article ID: 054. 
[4] Ben-Ari, Y., Merlob, P., Hirsch, M. and Reisner, SH. (1986) Congenital Depression of the Neonatal Skull. European Journal of Obstetrics Gynecology and Reproductive Biology, 22, 249-255. https://doi.org/10.1016/0028-2243(86)90073-0

[5] Fantacci, C., Massimi, L., Capozzi, D., Romano, V., Ferrara, P. and Chiaretti, A. (2015) "Spontaneous" Ping-Pong Fracture in Newborns: Case Report and Review of the Literature. Signa Vitae, 10, 103-109. https://doi.org/10.22514/SV101.042015.11

[6] Gezmu, A.M. and Mazhani, L. (2017) A Case Report of Significant Congenital Depressed Skull Fracture after Cesarean Section Delivery. African Journal of Medical and Health Sciences, 16, 123-125. https://doi.org/10.4103/ajmhs.ajmhs_28_17

[7] Aliabadi, H., Miller, J., Radnakrishnan, S., Mehta, A.I., Thomas, K., Selznick, L., Goldberg, R., Grant, G. and Fuchs, H. (2009) Spontaneous Intrauterine "Ping-Pong" Fracture: Review and Case Illustration. Neuropediatrics, 40, 73-75.

https://doi.org/10.1055/s-0029-1234108

[8] Steinbok, P., Flodmark, O., Martens, D. and Germann, E.T. (1987) Management of Simple Depressed Skull Fractures in Children. Journal of Neurosurgery, 66, 506-510. https://doi.org/10.3171/jns.1987.66.4.0506

[9] Agrawal, S.K., Kumar, P. and Sundaram, V. (2010) Congenital Depression of the Skull in Neonate: A Case of Successful Conservative Management. Journal of Child Neurology, 25, 387-389. https://doi.org/10.1177/0883073809338520

[10] Hanlon, L., Hogan, B., Corcoran, D. and Ryan, S. (2006) Congenital Depression of the Neonatal Skull: A Self Limiting Condition. BMJ Journals, 91, F272. https://doi.org/10.1136/adc.2005.082347

[11] Mastrapa, T.L., Fernandez, L.A., Alvarez, M.D., Storrs, B.B. and Flores-Urueta, A. (2007) Depressed Skull Fracture in Ping Pong: Elevation with Medeva Extractor. Child s Nervous System, 23, 787-790. https://doi.org/10.1007/s00381-007-0354-1

[12] Saunders, B.S., Lazoritz, S., McArtor, R.D., Marshall, P. and Bason, W.M. (1979) Depressed Skull Fracture in the Neonate. Report of 3 Cases. Journal of Neurosurgery, 50, 512-514. https://doi.org/10.3171/jns.1979.50.4.0512

[13] Tovar-Spinoza, Z.S. and Kim, P.D. (2012) Congenital Depressed Skull Fracture in the Absence of Trauma: Case Report and Literature Review. Research and Reports in Neonatology, 2, 11-14. https://doi.org/10.2147/RRN.S29666

[14] Dharmaraj, S.T., Embleton, N.D., Jenkins, A. and Jones, G. (2009) Depressed Skull Fracture in a Newborn Baby. BMJ Journals, 94, F137. https://doi.org/10.1136/adc.2008.148718

[15] Suneja, U., Prokhorov, S. and Rajegowda, B. (2015) Depressed Skull Fracture in a Term Newborn Infant. Pediatrics and Therapeutics, 5, i109. https://doi.org/10.4172/2161-0665.1000i109

[16] Arifin, M.Z., Gill, A.S., Anwar, A.D., Djuwantono, T. and Faried, A. (2013) Spontaneous Depressed Skull Fracture during Vaginal Delivery: A Report of Two Cases and Literature Review. Indian Journal of Neurotrauma, 10, 33-37. https://doi.org/10.1016/j.ijnt.2012.12.001

[17] Basaldella, L., Marton, E., Bekelis, K. and Longatti, P. (2011) Spontaneous Resolution of Atraumatic Intrauterine Ping-Pong Fractures in Newborns Delivered by Cesarean Section. Journal of Child Neurology, 26, 1449-1451. https://doi.org/10.1177/0883073811410058

[18] Staels, W., Lefevere, J., Decaluwe, W., Vantomme, N. and Philippe, G. (2012) Pingpong Skull Fracture in the Newborn: To Treat or Not to Treat? Journal du Pédiatre Belge, 14. 
[19] Preston, D., Jackson, S. and Gandhi, S. (2015) Non-Traumatic Depressed Skull Fracture in a Neonate or "Ping Pong" Fracture. BMJ Case Reports, 2015, bcr2014207077. https://doi.org/10.1136/bcr-2014-207077

[20] Veeravagu, A., Azad, T.D., Jiang, B. and Edwards, M.S.B. (2018) Spontaneous Intrauterine Depressed Skull Fracture: Report of 2 Cases Requiring Neurosurgical Intervention and Literature Review. World Neurosurgery, 110, 256-262.

https://doi.org/10.1016/j.wneu.2017.10.029 